\section{Human Security in the Age of Electoral Democracy: Politico-Business Alliances in the Malang Regency, Indonesia}

\section{Rika Kurniaty ${ }^{\text {a* }}$}

${ }^{a}$ Graduate School of International Relations-Ritsumeikan University, 56-1 Toji-in Kitamachi, Kita-Ku, Kyoto 603-8577, Japan

b Brawijaya University, Jl. Veteran Malang, Malang 65141, Indonesia

Received: November 30, 2018/ Accepted: August 21, 2019

\begin{abstract}
This study discusses the politico-business configuration of electoral democracy and its impact on human security in Malang. Indonesia's reforms in the post-Soeharto era marked by implementing new institutions of democracy through direct local elections (Pilkada), where people acquire their rights to directly determine their executive leader at both national and regional levels. Democracy institution is believed would naturally lead to greater human security. However, evidence -from the cases experienced in Malang- reveals a different result. The introduction of democratic institutions harmed human security because predatory alliances hijacked it. Liberal space as well as the opening up of elite competitions, provided by democracy, interfered with local politics. Both local politics and economic spheres were dominated by political and business elite coalitions. Also, the sustainability of good governance and democratic institutions tends to be dictated by the interests of these predatory elite alliances.

Although there have been abundant studies on Indonesia's democratization and decentralization, the problem of human security in the democratization process has rarely been conducted. This study, therefore, aims to reveal the practice of politico- business alliances in Malang that take over public resources and local budgets for their interests through the democratic institution. The significance of this study is an empirical contribution to develop an understanding of the process of how democratic institutions are hijacked by a few people (local elites) by seizing regional resources and sacrificing human security.
\end{abstract}

Keywords: electoral democracy, human security, politico-business alliance, Malang Regency

Abbreviations:

\begin{tabular}{|c|c|c|}
\hline APBD & : & $\begin{array}{l}\text { Anggaran Pendapatan dan Belanja Daerah (Local } \\
\text { Government Revenue and Expenditure), local } \\
\text { government budget }\end{array}$ \\
\hline DPD & : & $\begin{array}{l}\text { Dewan Pimpinan Daerah, the regional board of } \\
\text { political parties }\end{array}$ \\
\hline DPR & : & $\begin{array}{l}\text { Dewan Perwakilan Rakyat, } \\
\text { Representative Council }\end{array}$ \\
\hline DPRD & : & $\begin{array}{l}\text { Dewan Perwakilan Rakyat Daerah, Regional } \\
\text { People's Representative Council, regional } \\
\text { legislature }\end{array}$ \\
\hline Golkar & : & Golongan Karya, Functional Group Party \\
\hline Gerindra & : & $\begin{array}{l}\text { Partai Gerakan Indonesia Raya, Greater } \\
\text { Indonesia Movement Party }\end{array}$ \\
\hline KPK & : & $\begin{array}{l}\text { Komisi Pemberantasan Korupsi, Corruption } \\
\text { Eradication Commission }\end{array}$ \\
\hline KPUD & : & $\begin{array}{l}\text { Komisi Pemilihan Umum Daerah, Regional } \\
\text { General Elections Commission }\end{array}$ \\
\hline MCW & : & Malang Corruption Watch \\
\hline LHKP & : & $\begin{array}{l}\text { Laporan Harta Kekayaan Penyelenggara Negara, } \\
\text { State Administration Assets Report }\end{array}$ \\
\hline LKPJ & : & $\begin{array}{l}\text { Laporan Keterangan Pertanggungjawaban, } \\
\text { Government Accountability Statement }\end{array}$ \\
\hline PAN & : & $\begin{array}{l}\text { Partai Amanat Nasional, National Mandate } \\
\text { Party }\end{array}$ \\
\hline PDI-P & $:$ & $\begin{array}{l}\text { Partai Demokrasi Indonesia Perjuangan, } \\
\text { Indonesian Democratic Party-Struggle }\end{array}$ \\
\hline Pilkada & : & $\begin{array}{l}\text { Pemilihan Kepala Daerah langsung, Direct } \\
\text { Election for Local Leaders }\end{array}$ \\
\hline PKB & & $\begin{array}{l}\text { Partai Kebangkitan Bangsa, National Awakening } \\
\text { Party }\end{array}$ \\
\hline
\end{tabular}

\section{Introduction}

Since the fall of authoritarian Suharto in 1998, Indonesia's political system has changed from an authoritarian and centralistic regime to a decentralized democratic government. Indonesia initiated various politico reforms, and these changes included the introduction of a multi-party system (there were hundreds of political parties established between 1998 and 1999, and 48 parties participated in the 1999 elections). The most significant reform in Indonesia in the new democratization era was the decentralization policy formed during the reign of President Bacharuddin Jusuf Habibie. New democratic institutions (i.e., free and fair direct local elections- Pemilihan Kepala Daerah, Pilkada) that make it possible for people to influence the decision-making process- which affects people's lives- were also introduced and put into effect in 2005 .

\footnotetext{
Corresponding Author

E-mail:rika_kurniaty@ub.ac.id
} 
After nearly 20 years of implementation, decentralization policy and democratization in Indonesia have shown varying results. Several studies on contemporary Indonesia have explored and highlighted the positive and negative aspects of Indonesia's decentralization and democratization process $[1][2][3][4][5][6]$. In post-Suharto democracy, the power of predators previously incubated under the New Order could survive and adapt to the new democratic atmosphere [11]. Vedi R Hadiz and Richard Robison revealed that oligarch's traces have long been woven into the political structure of Indonesia [11]. If, during the Soeharto era, the oligarchs worked in an authoritarian system of government, in the current democratization era, they work in electoral systems, political parties, parliaments, and utilize money politics to influence voter support [2][11][12].

In Indonesian modern democracy, some scholars concluded that money politics has significantly colored the Pilkada. Money politics occurs in the form of direct or indirect methods (material objects are given instead of money). Besides, grassroots organizations have turned into political vehicles of local elites to win the contestation [3][1]: electoral fraud, money politics, rent-seeking, patronage politics, and the politico business coalition have endemic to the political realm [4] [7] [8] [10] [13]. Also, expensive political costs have caused the involvement of the business elite in Indonesia's electoral process.

Several scholars have reviewed this involvement of business actors in Indonesia's democratization system. Nevertheless, although there have been studies discussing the Indonesian business political alliance, it has not been sufficiently studied on business elites who choose to be 'actors behind the scenes.' Discussions and studies of business-political relations in Indonesia are usually trapped in the discourse of business elites who immediately engaged in politics: (e.g., Surya Paloh, Jusuf Kalla, Aburizal Bakrie, and Hari Tanoe) [14] [15]. The studies related to business and politics are still very narrow, especially at the local level. The type of business elites behind the scenes that support certain candidates in the local elections has received less attention than those who are directly involved in politics as political actors.

Therefore, this paper attempts to fill in the gaps in the study: politico-business elites and argues that discussion about local politics requires also another picture by scrutinizing the business elites that 'play' behind the scenes in the political realm. The article focuses on the configuration of a political business alliance in the Malang Regency in the era of electoral democracy. Similar to some other regions in Indonesia, local politics in the Malang Regency is also characterized by strong connections between political and business elites that produce negative consequences for the development of good governance and human security of the Malang people. However, this study does not measure the details of the impact of business political alliances on human security. Instead, this study examines how the practice of the politico-business alliance took place in the era of direct elections in the Malang
Regency, including how local elites utilize the democratic institution as a tool to achieve their interests that harm Malang people's human security.

The organization of this paper is divided into five parts. Following this introduction, the next section deals with the methodology of the study. The third section looks at the framework of human security that provides a brief understanding of human security in the modern electoral democratic institutions. The next section, elaborates and discusses the results of case study in the process of the politico-business alliance in the Malang Regency. Finally, the last section discusses the general conclusion of the study.

\section{Methodology}

This study employs qualitative research to a case study, and the principle of interpretivism as a methodology - the choice of the methods based on the case to look at the problem. It is limited by the dimensions of the location, the actors and the subject, the focus and the substance under study.

The case study in the Malang Regency, with the local business elites and local government leaders/ bureaucrats as the object of the study. The topic chosen limited to the form of business-political relations between the local elites in the Malang Regency.

This study is grounded in data from intensive fieldwork. Primary data were obtained from direct observations, interviews with competent critical stakeholders involved in the policy process. Interviews were addressed to local political elites, government bureaucrats, local staff, local observers (academics, NGOs, and community-based organization leaders and activists), local businesspeople, political consultants, and residents affected by the government's policy choices. Secondary data was found from documents of a local development planning agency including, for example, regional budget expenditure reports, the Malang Corruption Watch's documents, and press releases, State Administration Assets Report, documents from the regional election commission and the election supervisory body. This includes data from literature sources in the form of books, previous research, as well as data from both print and electronic mass media related to the Malang case study.

\section{Electoral Democracy and Human Security Framework}

Democracy and Human Security have vital links. Many scholars are optimistic that the adoption of democracy in a country can naturally lead to increased human security. The idea of human security was introduced by the United Nations Development Program (UNDP) since the 1990 . Human security is defined as the protection of survival, livelihood, and human dignity [17]. The concept of human 
security consists of seven dimensions: economy, food, health, environment, personal security, society, and politics [16]. This security dimension is related to human rights to be free from fear, desire and freedom to live in dignity [16]. Security also means free from a variety of risks [18]. Freedom from fear focuses on protecting human rights, while freedom from desire, and emphasizes economic aspects that are parallel to development.

The concept of human security, however, is still contested among scholars; some scholars oppose the notion of human security, while some support it. This human security debate related to the broad human security definition produced by the UNDP has the Japanese approach, and the Canadian approach. While the Japanese approach binds human security to the concept of development, the Canadian approach has a narrower definition that focuses on human security in conflict areas. Furthermore, the broad view of human security is presented by the UNDP and the Human Security Unit at the UN Office for the Coordination of Humanitarian Affairs (UNOCHA). The UNDP declared that humans must be guaranteed freedom from desire, freedom from fear, and freedom to live in dignity [16][20][23]. In line with the UNDP approach, the Japanese approach protects people from all types of violence [21] and encourages people to develop protection ways for themselves. The human security under the Japanese approach involves education, equality of economic opportunities, adequate health care, and gender equality [19].

The concept of human security by the UNDP has been the subject of criticism because of its broad interpretation, yet it also inspired many scholars and countries to develop a concept of human security. Meanwhile, the Canadian approach claims that human security as envisaged by the UNDP is not effective for people protection because it lacks precision, and fails to determine particularly vulnerable groups. Therefore, the Canadian approach campaigned for a more narrow understanding of human security, which was focused more on people protection from the threat of violence and non-violence [18 [22].

In the context of the electoral democracy and human security, this paper argues that the Japanese approach on human security fits with the case in the Malang Regency. To achieve human security goals, the Japanese approach emphasizes freedom from desires and is primarily concerned with sustainable development. This article ties human security to a series of welfare domains in the Malang regency. Welfare refers to conditions in which human security is realized. This condition must reflect freedom from three aspects: poverty, inequality, and vulnerability [22]. Specifically, it includes income, health, education, environment or biodiversity, political freedom, and democracy [18]. Poverty, inequality, and vulnerability are influenced by political freedom and democracy. Both political freedom and democracy make it possible for people to influence the decision-making process that affects their lives. One indicator of political freedom and democracy is the implementation of free and fair elections, as well as the political participation of the people.

People's political participation in Indonesia's democratization process is reflected in the implementation of Pilkada. However, the new Indonesian electoral democracy requires incredibly expensive costs that only a few wealthy people could participate in political contestation. In order to bear these political costs, the candidates who do not possess assets, built a network with business elites. Therefore, the business elites would bear the political costs of the candidates. However, the network between political elites and business elites followed by various material reward transactions and agreements if, later, the candidate would be elected as a regional head.

These political transactions often harm the people's welfare, because the predatory practice of the political alliance between businesses prioritizes profits and economic division among them. Many of the lands that are a source of livelihood for the community are converted into objects of exploitation by the elites. The politico-business coalition action threatens human security (refers to aspects of protecting and empowering people from various threats to human life, such as poverty and environmental degradation) [22].

\section{Results and Discussion}

This section discusses the case study of the Malang Regency, where local elite alliances utilize the democratic institution, Pilkada, for their interests. With the implementation of the new electoral system, the practice of predatory alliances between political elites and business elites is rampant in the process of Pilkada. It is known that after the 1998 reformation, there was hope that Indonesia would begin a rapid transition to a liberal market and liberal democracy. However, Indonesia's transformation into a liberal market economy and democracy is unclear and uncertain [24]. Vedi Hadiz and Richard Robison point out that deregulation has been selective, and the state continues to play a critical role in shaping and controlling access to the market. Besides, the predatory alliances of state and business oligarchies stamped their ascendancy into the economic and political spheres [9]. This alliance not only occurred at the national level but also at the local level, in this case: the Malang Regency.

Furthermore, the results and discussion section will analyze in more detail, the practice of the business-political alliances in the Malang Regency, in which the business elites become 'actors behind the scenes' in the local political sphere. This section is divided into four sub-sections: the overview of Malang socio-economic condition; the local political configuration; the emergence of politico-business alliances; and the discussion related to electoral democracy and human security. 


\section{Overview: Socio-Economic setting of the Malang Regency}

The Malang Regency is the most extensive district in East Java after Banyuwangi, which is located in the south-central part of the East Java Province. The Malang Regency is divided into 33 sub-districts (subdivided into villages/kelurahan). The Malang Regency was once part of the Greater Malang area or Metropolitan Malang.

Before 2011, the center of government was in the Malang municipality. The center of government later was transferred to Kepanjen, following the instructions of local government regulation number 18 of 2008, that mentions Kepanjen as the capital of the Malang Regency [32]. Referring to the breadth of the Malang Regency, recently there has been an active discourse in the DPRD on the expansion of the Malang Regency into two divisions. The Malang Regency is included in the list of Special Committees for the Regional Medium-Term Development Plan (RPJMD) of East Java as an area to be divided (Jawa Pos-Radar Malang, 18 March 2017). Compare to other regions in East Java, the Malang Regency has the largest population with 2.576 .596 people that consist of 50.26 percent men and 49.74 percent woman [30].

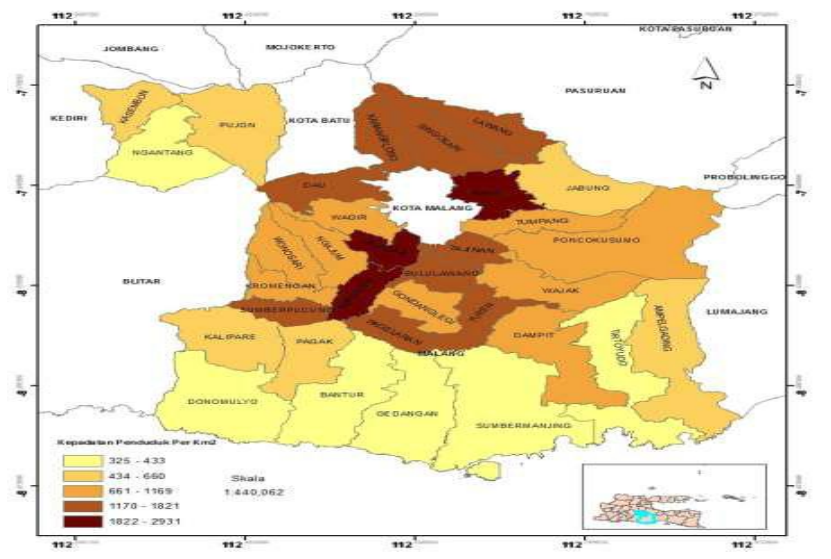

Figure 1 Malang Regency map

Source: Statistics of the Malang Regency 2018

The Malang Regency has a geographical uniqueness as a consequence of decentralization and regional expansion policies, where two regencies and one municipality are connected to form a region the 'Malang Raya'.

Administratively, Malang was formerly the part of the Karasidenan area during Dutch colonialism. As one of the largest areas in East Java, the Malang Regency has outstanding potential and experienced development in various sectors. Data from the Malang investment office revealed that the agricultural sector contributed $29.15 \%$, the trade, hotel and restaurant sector $23.82 \%$, and the industrial sector $19.71 \%$ [25].

These development sectors open the possibility to enlarge various investment areas in the Malang Regency.
The promise of high economic benefits in the Malang Regency caused the involvement of business elites in the political field. Thus, Malang economic development remains one of the areas of opportunity for business elites to increase their material profits.

Moreover, to be able to enter and intervene in economic policies in the region, the business elites critically require to establish a relationship with regents (as the highest holder of regional authority). Therefore, the business elites would financially support the candidate regents in Pilkada. The high political costs in the elections, the shift in the political behavior of the people from idealism to a pragmatic attitude, and the change in the electoral system, resulted in higher levels of competition among candidates. The requisites among local business elites and political elites are accommodated through new democratic institutions that provide space for political transactions. In short, the interests of both political elites and business elites find momentum in Pilkada system.

\section{Pilkada and local Political configuration}

To provide an understanding of the case study of the Malang Regency the author discusses how business elites enter the political arena in the age of electoral democracy by analyzing regional elections development in the Malang Regency.

After the fall of the New Order in May 1998, the first civilian regent of the Malang Regency was the Late Mochammad Ibnu Rubianto. Malang DPRD members selected the late Ibnu Rubianto in the first fair and democratic election, in 200o. During his tenure (between 2000 to 2005), Ibnu Rubianto passed away, in 2002. He later was replaced by his deputy regent, Sujud Pribadi who held the position of regent until 2005. Subsequently, Sujud continued to stay in office by winning the Pilkada in 2005. The 2005 Pilkada was the first direct election in the Malang Regency following the new electoral policy and the implementation of the Presidential election, in 2004. Based on Law No 32 of 2004, the regent and the deputy regent would be elected directly by the people (after previously being elected by DPRD members).

In Malang's 2005 Pilkada, Sujud Pribadi paired with Rendra Kresna. Both were supported by the coalition of the Golkar party and PDIP. There were 1,206,366 voters who participated in the the 2005 election. The final results revealed that Noeryanto and Zainal Fahris obtained 121,209 (10 percent) votes, Sujud Pribadi and Rendra Kresna received 788,033 (65. 3 percent) votes, while Dade Angga and Kamilun Muhtadin received 268,834 votes (22.3 percent) [29]

Sujud Pribadi, the winner in the 2005 Malang regent election, benefited from his position as the incumbent and had bureaucrat experience as deputy regent. Therefore, compared to the two other competitors in the 2005 Malang Pilkada, Sujud Pribadi, and Rendra Kresna had stronger power and local resources. Sujud Pribadi was the incumbent 
acting regent who replaced the Malang regent, while Rendra Kresna was a senior Golkar Party politician, who once served as Chair of the Malang Regency. He was a Golkar Party member and a member of the Malang Regency, DPRD. Rendra Kresna also had rapport with the workers because he had served as Chair of the All Indonesian Workers Association (SPSI) of the Malang Regency. The Golkar Party and the PDIP were strategic political vehicles because the two parties had the most seats in the 2004 legislative elections. Finally, Sujud Pribadi and Rendra Kresna held the regent office until 2010.

In the 2010 regional elections, Sujud Pribadi from PDIP was not allowed to run again, because he had served two terms in office as a regent. In the 2010 regional election, there were divisions within the PDIP and the Golkar coalition. Golkar promoted Rendra Kresna as a candidate regent for 2010 to 2015 periods. Golkar built a new coalition with the Democratic Party led by President Susilo Bambang Yudhoyono. The coalition of Golkar and the Democratic party carried Ahmad Subhan (construction entrepreneur) as the deputy regent candidate. Prosperous Justice Party (Partai Keadilan Sejahtera, PKS) and the United Development Party (Partai Persatuan Pembangunan, PPP) later joined the coalition as supporting parties.

Rendra Kresna's competitors were Geng Wahyudi (Police officers in the intelligence and security unit)-Abdul Rahman (Chairperson of the local parliamentary PKB faction) carried by PDIP and PKB. Also, Agus Wahyu Arifin (former Head of the Malang Health Service) -Abdul Mujib Syadzilli (NU Kiai) were represented by the Gerindra party, the Hanura party, and PKNU. Rendra Kresna-Ahmad Subhan finally won the Malang Regency election contest for the 2010-2015 periods.

The victory of Rendra Kresna-Ahmad Subhan in the Malang regional election in 2010 had been predicted in many quick counts of various survey institutions. The surveys revealed that the pair Rendra Kresna and Ahmad Subhan would win the votes above 6o percent. Such as the Indonesian Survey Circle (LSI) has shown that Rendra Kresna-Ahmad Subhan excelled from the other pairs of candidates with 61.63 percent. While Geng Wahyudi-Abdul Rahman received 30.17 percent, and Agus Wahyu Arifin-Abdul Mujib Syadzili obtained 8.20 percent [29].

It is not astonishing that the incumbent regent, Rendra, won the 2010 Pilkada. It is known that in the electoral democracy, the political power of incumbent candidates is very high. They certainly already knew precisely the political map of the electoral regions. The public perception of incumbents is to usually access all the networks and to have a tendency to abuse power. This condition had most likely occurred in the Malang Regency, given that incumbent regent had direct access to local policy and budgeting processes. The incumbent could encourage budget allocation and disbursement to his advantages and could get certain political benefits from policies and programs during the tenure. In addition, this strategic position could increase popularity in the community. Incumbents could also influence bureaucracy and get more attention from the mass media. They benefited from their position by establishing personal patronage networks and collaboration with the business community, mass media, religious leaders, local politicians, NGOs, and mass-based organizations. In addition to these advantages, incumbents- are certainly better known to the public. The political machinery of the Golkar and the Democratic Party succeeded in socializing and introducing the figure of Rendra Kresna and Ahmad Subhan.

Moreover, in the 2010 Malang direct local election, Geng Wahyudi-Abdul Rahman actually had a high probability of winning the election. However, they could not utilize the full strength of the voting capital in the 2009 legislative elections. PDIP and PKB's voting capital in the 2009 legislative elections had reached 40.70 percent, not too much different from the sound capital of the Golkar, Democrat, PKS and PPP coalitions (46.05 percent) [29]. One of the triggers for the defeat of Geng Wahyudi and Abdul Rahman was their figures were less influential than the pair of Rendra Kresna and Ahmad Subhan, who were carried by the Golkar, Democrat, PKS and PPP coalitions[25]. The figure of Geng Wahyudi was less attractive to the public than the figure of Rendra Kresna. To offset the figure of Rendra Kresna and Ahmad Subhan, the total obtained votes by PKB and PDIP in the legislative elections could be quite good political capital.

Several forms of serious violations were found in the 2010 Pilkada process. The campaign team from Geng Wahyudi (PDIP) stated that there was a practice of money politics carried out by the campaign team of the pair Rendra Kresna-Ahmad Subhan. Money politics occurred in the form of distributing packages containing two kilograms of rice and one kilogram of sugar with images of the faces of Rendra Kresna-Ahmad Subhan. There was also a distribution of cement, wall clocks, and glasses.

Likewise, the next Pilkada in 2015, made Malang local politics become very vibrant. There were three candidate pairs who participated in the latest 2016 election: 1. Incumbent candidate Rendra-Sanusi (supported by the party coalition of Golkar, PKB, Nasdem, Democrat, Gerindra, PKS and PPP); 2. Dewanti Rumpoko-Masrifah Hadi (Supported by PDIP; the most voted for party in the Malang Regency); 3. Nurkholis-Muhammad Mufidz (independent candidates with large mass bases from several sub-districts). The political dynamic could be recognized by the reappearance of the incumbent regent, the emergence of female candidates, and the participation of independent candidates. From these situations, the events at the Malang Pilkada, were considered to be only a battle between political elites and political parties. But behind that, there is a hidden alliance between the political elite and the business elite that sacrifices public sphere and human security. 


\section{The Entrance of Business in the Malang political sphere}

A critical feature of the transition from the New Order to democratic regimes in the Malang is the sustainability of elites, exemplified by two prominent local political elites: Sujud Pribadi and Rendra Kresna. Sujud Pribadi was the regent for two periods from 2002 to 2010, and Rendra Kresna was his successor, who was elected in the direct Pilkada from 2010 to 2015 and was re-elected in 2015-2020. The incumbent regent, Rendra Kresna, was a Golkar Party cadre before becoming chairman of the new party, National Democrat (Partai Nasional Demokrat, Nasdem). He was a member of the representative council of the people of the Malang Regency from the Golkar faction in 1997. Rendra's political career skyrocketed in 2004, when he was elected as chairman of the DPD; Golkar of Malang. Based on Rendra Kresna's political background, he could be categorized as an old, established elite.

In addition, the Network and party coalition mentioned in the above discussion, the dynamics of local politics in Malang Regency were inseparable from transactional politics. The victory of regent candidates in Pilkada was often related to the involvement of business elites in local politics. It cannot be denied that the new electoral system requires a high political cost. Thus, candidates who do not have the economic capital to finance the campaign process, cooperate with local business elites.

In Malang Pilkada, the majority of local business elites gave 'support' to the candidates. From the interview with one local well-known entrepreneur, it is known that prior to Pilkada, local entrepreneurs had to contribute to support candidates individually or under coordination. However, among the Malang, these local entrepreneurs or business elites, there is one prominent figure in Malang local politics: (in this article the author mentioned the pseudonym as "the Big Boss"). The victory of Rendra Kresna in Pilkada was inseparable from the role of local business elite, especially this Big Boss. The major supporter funding of Rendra Kresna was the Big Boss who has many assets and networks at the local and national levels. The Big Boss is a well-known figure to the people of the Malang Regency as successful business elite, not a political actor. He can appear as a 'ruler' in the local economic field with extensive business and wealth ownership.

The "blessing" to Rendra Kresna's triumph in Pilkada was shown through the form of financial support. Without the backing of the Big Boss, it was difficult for Rendra Kresna to be able to finance political costs in the Pilkada. Rendra Kresna was not wealthy enough to meet the high political costs. From the state administration assets report (laporan harta kekayaan penyelenggara negara, LHKPN)released by the Indonesian eradication corruption commission, Rendra Kresna's total assets in 2001, were only Rp. 767.23 million, including three cars: Daihatsu 'Taft ' car, 'Hijet' car, and 'Zebra' car, and five land parcels valued at Rp 546.6 million [32]. However, it significantly increased to Rp. 3,222,448.98 on December 31, 2014 [32].

Material support from the Big Boss is partly free, but often is a debt that must be paid through government projects given to the Big Boss's companies. The relationship between business elites and bureaucrats in the Malang Regency forms a mutually- beneficial relationship [34]. Business elites support their networks by providing material needs and providing luxurious facilities to the ruling elites. The government officials are given financial guarantees and position protection, and in return for the funding support, business elites gain priority access to government projects through a "project bound" system and the transfer of land functions for business expansions [34]. The relationship built between the business elite and the ruling elites is a transactional and mutually beneficial relationship. Interchangeable goods are economic modalities and access to government policies.

This study found that it was not a secret for the Malang citizens, that the Big Boss changed the face of Malang. He emerged in the Reformation era after the fall of the authoritarian regime. He benefited from the uncertain condition that resulted during the transition periods by managing security money from ethnic Chinese who felt insecure because of the racial issues during reformation. Most of the security money from the ethnic Chinese was given to the police and the military officers. From this process, the Big Boss established a business relationship with government bureaucrats and law enforcers. His business later expanded to cover various fields ranging from the night entertainment businesses and hotels, to construction businesses.

Moreover, support and disbursement of campaign funds or campaign material by elite business and the Big Boss have an impact on increasing the electability of regional head candidates. 'There is no free lunch,' or, it is impossible to get something free. This saying can represent the relationship of contractual transactions between candidates and business elites before and after the elections in the Malang Regency. Business elites have included these regional head candidates in transactional contracts to return what they have spent by demanding compensation in terms of project implementation. After the election, local business elites would wait for the allotment of infrastructure projects. Especially for the Big Boss; he gained more priority for implementing local government projects by making it easier to compete in the bidding process. Numerous Malang government projects (partly in Batu) were carried out by his company without a tender process [34]. From the results of the interview, the authors found that the 'tender process' was very complex, often the name of the winning company was only a sub-contract for implementing the tender. Though almost all tenders were controlled by the Big Boss's company. In short, what happened on the surface was not in accordance with what actually happened.

At present, the Big Boss attempted to build a positive image in the community by performing social activities. As 
a result, the Malang people consider the Big Boss presence as a "Godfather." Local media described him as a successful and popular elite that close to the Malang community. This Big Boss conducted his social activities through one of his company offices located in the center of the Malang. Even though, the Big Boss was not a Muslim, during the past 12 years, the company regularly held Islamic week activities in the Malang area. The program varied, ranging from compensating thousands of orphans in the Malang Regency, building a 'mosque' in front of the office and filling it with various activities during the month of Ramadan until Ied Fitr. The Big Boss recognized well the culture of the people of the Malang Regency. As the Muslim majority region, it was easier to be approached through the lines of the local Kyai or religious teachers. The Big Boss, therefore, formed a good and strong relationship with the Kyai in the context of building a good 'image' in the community.

In brief, although the Big Boss did not immediately take the role as a ruling elite in the Malang Regency, he could influence the course of Malang local politics and government. In this case, the involvement of business elites could be seen in at least two ways: namely the ability to access government projects, and also the position as one of the contributors to the candidate for the Pilkada events, particularly 2015 Pilkada.

The Pilkada in 2015 was not much different from the previous election practice, although the government bore the costs of the campaign through the regional budget and expenditure budget. The budget could not cover all the campaign costs. This high cost, which in turn opened an opportunity for business elites to enter as donors for candidate pairs.

To minimize the threat of failure of candidate pairs, local entrepreneurs and the Big Boss also applied a system to stand on many legs. This system meant that the locals provided the supports for all candidate pairs with different portions depending on the electability of each candidate. The goal was clear: whoever wins the contest, the local business elite and Big Boss had invested in their victory.

The expensive cost of politics in electoral democracy of business elites was solved pragmatically by alliances with business elites. This resulted in sacrificing the public interest and human security. About two months ago, (when this article was drafted), on October 15, 2008, Rendra Kresna allegedly received a bribe of $\mathrm{Rp} 3.45$ billion related to providing facilities to support education quality improvement at the Malang District Government Education Office and at several government projects of the Malang Regency [35]. The corruption eradication commission also arrested the business elites related to Rendra Kresna case but not the Big Boss. The money received by Rendra Kresna was allegedly used for debt payment during the campaign [36].

It can be concluded that business elites mostly choose direct regional elections as an entrance into the political environment. The high cost of direct elections is a significant factor in the involvement of entrepreneurs in politics. The continuity of the relationship then forms a relationship that tends to lead to patronage relations and form a political oligarchy that has a direct impact on the sustainability of human security.

\section{Politico- business alliance and Human Security}

In the context of the electoral democracy and politico-business alliance, this paper argues that the Japanese approach to human security fits with the case in the Malang Regency. The Japanese approach requires the human security condition must reflect freedom from three aspects: poverty, inequality, and vulnerability [22]. Particularly, it includes political freedom and democracy (beside income, health, education, and environment or biodiversity). The practice of politico-business alliances has harmed regional development and political participation. The adverse impact is the chance of rampant corruption and corrupt behavior among local elites. This can be seen in the cases of Rendra Kresna and the Big Boss, whereby the power between the political and the business elites has led to fraudulent power that undermined the bureaucracy in the region.

In addition, politico-business alliances could also reduce the quality of local-level democracy where competition in local political contest becomes unbalanced and unfair. Politico-business alliances in which a handful of elites control local resources will always harm society's welfare and human security. The alliance has hijacked a system of electoral democracy aimed at the interests of the people in general which has become the neglect of the people's welfare. Politico-business alliances in the Malang Regency has resulted in the control of government assets to a handful of people or groups close to the authorities so that inequality impedes economic growth.

Moreover, in the case of the Malang Regency, the predatory practice between business and political elites has spawned a cycle of corruption and the practice of nepotism. Corruption correlates with human security because with increased corruption, human security decreases [41].

Therefore, relations between business elites and political elites in the Malang form mutual alliances, that lead to a patronage relationship. Although new electoral democracies have been put in place, political elites in the Malang do not have "credible commitments" and therefore, need to rely on patronage to get support. Patronage is alleged to have promoted corruption, client public services and more legal rules weak. So, besides establishing a political oligarchy, relations between business and politics in the Malang region are also often interwoven in a patronage relationship. The concept of patronage politics merely is interpreted as a relationship that occupies one party as a patron (has a higher position) and the other party becomes a client (has a lower position). In the context of local elites and political or ruling elites in Malang Regency, political patronage occurs with the tendency of the position of business elites to be stronger than those of the ruling elites. 


\section{Conclusion}

It is expected that Pilkada as democratic institutions would facilitate greater access to public officials and accountability, which in turn increases the demand of goods and public services delivery, such as access to adequate food, housing, health, education, and employment. Overcoming the unequal distribution of power in society is another critical factor in improving human development policies and outcomes.

However, the case of the Malang Regency showed that the local political elites and structured business elites had utilized a new institution of democracy for the sake of their personal economic interest. Although in Pilkada, people have the right to vote directly, the choice was dominated by a handful of elites. Also, the process of the relationship between business elites and bureaucrats in the Malang Regency occurred by exploiting the opportunities provided by electoral democracy. Business elite and political elite coalitions in the Malang Regency often misused power and authority, such as corruption and land conversions for personal interest purposes. They sacrificed the public interest to gain power and enrich their wealth.

The oligarchic theory and political cartel could be borrowed to dissect the Malang political and economic condition. The relationship between businesspeople and government bureaucrats in the Malang region is a transactional relationship that lead to patronage politics. High-cost elections made the occurrence of business-political transactions.

The predatory transactions between business and political elites spawned a cycle of corruption and the practice of nepotism. In practice, these political transactions often sacrificed aspects of human security, because business interests often decide government policies. Although not all of the business elites are immediately directly involved in politics (or having public offices), business elites in the Malang Regency have the power to affect government policies. Their strength is higher than that of government officials. In Malang case, the Pilkada provides an opportunity for the emergence of 'local bosses' and political patronage.

\section{Acknowledgments}

The study is a part of ongoing Doctoral thesis research in Ritsumeikan University-Japan on Indonesia's Decentralization and Electoral Democracy: Changes and Continuities of Local Elites in East Java.

\section{References}

[1] Aspinall, E \& Sukmajati, M. (eds), 2016. Electoral Dynamics in Indonesia: Money Politics, Patronage and Clientelism at the Grassroots.Singapore: NUS Press.

[2] Buhler, Michael., 2009. The Rising Importance of Personal Networks in Indonesian Local Politics: An Analysis of District Government Head Elections in South Sulawesi in 2005, in Maribeth Erb and Piyambudi
Sulistyanto, Deepening Democracy in Indonesia? Direct Elections for Local Leaders (Pilkada), pp. 101-124, Singapore: ISEAS.

[3] Choi, Nangkyung., 2009. Democracy and Patrimonial Politics in Local Indonesia. Indonesia, Vol. 88, pp. 131-164.

[4] Hadiz, Vedi R., 2009. The Dynamics of Political Economy Power in Post-Soeharto Indonesia. Jakarta: LP3ES. 2005.4[6] Bush, Robin. Nahdlatul Ulama and the Struggle for Power within Islam and Politics in Indonesia. Singapore: ISEAS.

[5] Kurniaty, Rika., 2014. Local Elites and Public Space Sustainability: the local elite roles in the presence and usage of public space in Malang Raya, Indonesia. Procedia Environmental Sciences 20 pp. 506-515.

[6] Ford, M. \& Thomas B. Pepinsky (ed)., 2015. Beyond Oligarchy. New York: Southeast Asia Program Publication.

[7] Crouch, Harold., 2010. Political Reform in Indonesia after Soeharto. Singapore: ISEAS.

[8] Fukuoka, Yuki., 2012. Politics, Business and the State in Post-Soeharto Indonesia. Contemporary Southeast Asia Vol. 34 No. 1, pp. 8o-100.

[9] Hadiz, Vedi R. \& Robison., 2014. The Political Economy of Oligarchy and the Reorganization of Power in Indonesia. In Michele Ford and Thomas B. Pepinsky (ed). Beyond Oligarchy. New York: Southeast Asia Program Publication.

[10] Hidayat, S., 2007. 'Shadow State? Business and politics in the province of Banten' in HS Nordholt \& Gav Klinken (eds.), Renegotiating Boundaries: Local Politics in the post- Suharto Indonesia, Leiden, KITLV Press.

[11] Bünte, Marco., 2009. Indonesia's Protracted Decentralization: Contested Reforms and Their Unintended Consequences, in Marco Buente and Andreas Ufen (ed), Democratization in Post-Suharto Indonesia, Oxon: Routledge.

[12]Dwipayana, AAGN Ari., 2009. High-Cost Democracy: Economic Dimension in the Electoral Democracy Process in Indonesia Post New Order. Journal of Social Science and Politics Volume 12, 3 March 2009. pp.257-39o.

[13] Klinken, Gerry Van., 2009. Patronage Democracy in Provincial Indonesia, in Olle Tornquist (ed). Rethinking Popular Representation. New York: Palgrave Macmillan.

[14]Winters, Jeffrey A., 2011. Oligarchy. New York: Cambridge University Press.

[15] Winters, Jeffery A., 2015. Oligarchy and Democracy in Indonesia. In Ford, $\mathrm{M}$ \& Thomas B. Pepinsky (eds). Beyond Oligarchy. New York: Southeast Asia Program Publication.

[16]Sen, A., 2014. Birth of a Discourse. In M. M. Owen, Routledge Handbook of Human Security. London: Cambridge.

[17] UNDP, 2014. Human Development Report: Technical Notes. Available at: http://hdr.undp.org/ [Accessed 10 November 2018].

[18] King, G. \& Murray, C. J., 20o1. Rethinking Human Security. Political Science Quarterly, 116(4), pp. 585-610.

[19] Gasper, D., 2014. Human Security: From Definitions to Investigating a Discourse. In: M. Martin \& T. Owen, eds. Routledge Handbook of Human Security. London and New York: Routledge, pp. 28-42.

[20] Wheeler, D., 2011. Freedom from Want, and Freedom from Fear. Journal of Human Security, 7(1), pp. 
37-52.

[21] Er, L. P., 2006. Japan's Human Security in Southeast Asia. Contemporary South East Asia, 28(1), pp. 141-229.

[21] McFarlane, S. N. \&Khong, Y. f., 2006. Human Security and the UN: a Critical History. Bloomington: Indiana University Press.

[22] The WB., 2011. Home: Measuring Poverty. Available at: The World Bank: http://web.worldbank.org/ [Accessed 10 November 2018].

[23]United Nations, 2007. Indicators of Sustainable Development: Guidelines and Methodology, New York: United Nations Public.

[24] Aspinall, E., 2013. A Nations in Fragments: Patronage and Neoliberalism in Contemporary Indonesia. Critical Asian Studies 45(1).

[25] Sobari,W., 2010. Patronage Driven Democracy: Emerging Local Politics in the post-Soeharto Indonesia. Surabaya: Airlangga University Press

[26] Haris, S \& Bunga N., 2017. Kota Batu Dalam Cengkeraman Oligarki. Available at: http://transisi.org. [Accessed 12 February 2018].

[27] Chiquita, M. 2018. Struktur Oligarki Kota Batu (Relasi Pengusaha Dan Pemerintah Di Kota Batu). Malang, Thesis, Brawijaya University.

[28] Malang corruption watch. 2018. Buntut Kekecewaan dan Rasa. Malu Warga Kota Malang. Available at: https://mcw-malang.org/buntut-kekecewaan-dan-rasamalu-warga-kota-malang/ [Accessed 14 September 2018].

[29] Tempo. Recapitulation Results of Malang Regent Election Protested, available https://nasional.tempo.co/read/270835/hasil-rekapitulas i-pemilihan-bupati-malang-diprotes/full\&view=ok.

[Accessed 10 September 2018].

[30] Statistics of Malang Regency. 2018. available at: https://malangkab.bps.go.id/ [Accesed on 14 August 2018].

[31] Mursyidi, Iman. 2007. Cengkraman Oligarki Langgengkan Dinasti Politik Kota Batu. Available at https://nusantara.news/cengkraman-oligarki-langgengk an-dinasti-politik-kota-batu/. [Accessed 14 August 2018].

[32] Zaenuddin H.M., 2013. Asal usul Kota-Kota di Indonesia Tempo Doeloe. Cetakan I.

[33] Aminudin, M., 2018. Bupati Malang Lapor Harta Kekayaan Terakhir 2014, Ini Rinciannya. Available at: https://news.detik.com/berita-jawa-timur/d-4250235/bu pati-malang-lapor-harta-kekayaan-terakhir-2014-ini-rinc iannya. [Accessed on 10 November 2018]

[34] Subekti, Tia., 2016. Relasi Patron Klien Antara pengusaha dan penguasa di Kabupaten Malang. Yogyakarta, Thesis, Gadjah Mada University, [35] CNN, 2018. Bupati Malang jadi tersangka. Available https://www.cnnindonesia.com/nasional/2018101117542112-337762/bupati-malang-rendra-jadi-tersangka-suap-da n-gratifikasi. [Accessed 20 November 2018].

[36] Kontan, 2018. Bupati Malang Rendra Korupsi Untuk Bayar Utang kampanye. Available at: https://nasional.kontan.co.id/news/bupati-malang-rend ra-korupsi-untuk-bayar-utang-kampanye. [Accessed 20 November 2018].
[37] Statistic of Malang Municipality, 2017. Malang Municipality in Figures 2017. Available at: https://malangkota.bps.go.id/. [Accessed 11 November 2018].

[38] Rachman, A., 2018. Wali Kota Malang Segera Disidang Terkait Kasus Dugaan Suap. Available at: https://nasional.kompas.com/read/2018/05/25/o9090831 /wali-kota-malang-segera-disidang-terkait-kasus-dugaa n-suap. [Accessed 15 November 2018]

[40] Aditya, S., 2017. Arema, Sebuah Jati Diri dan Subkultur Arek Malang. Available at: https://nusantara.news/arema-sebuah-jati-diri-dan-sub kultur-arek-malang/. [Accessed 10 November 2018].

[41] Piconne,T., 2017. Democracy and human security. Brookings Institution. Available at: https://www.brookings.edu/wp-content/uploads/2017/o 8/fp_20170905_democracy_gender_security.pdf [Accessed 15 November 2018]

[42] Tempo. 2013., Pertama Kali, Wali Kota Malang Dari Etnis Tionghoa. available at: https://nasional.tempo.co/read/483108/pertama-kali-wa li-kota-malang-dari-etnis-tionghoa. [Accessed 20 November 2018].

[42] Apinino, Rio.,2018. Asal-usul Kasus Suap yang Menjerat 40 Anggota DPRD Kota Malang. available at: https://tirto.id/asal-usul-kasus-suap-yang-menjerat-40anggota-dprd-kota-malang-cWPq. [Accessed November 2018]. 